\title{
Breathing pattern and central ventilatory drive in mild and moderate generalised myasthenia gravis
}

\author{
F García Río, C Prados, E Diez Tejedor, S Díaz Lobato, R Alvarez-Sala, J Villamor, \\ J M Pino
}

\begin{abstract}
Background-Myasthenia gravis is a specific autoimmune disease characterised by weakness and fatigue. Respiratory muscle weakness has been studied using the determination of maximal respiratory pressures, but the response of respiratory centres is not well characterised. This study was undertaken to determine the breathing pattern and the central ventilatory drive in patients with mild and moderate generalised myasthenia gravis.
\end{abstract}

Methods - Twenty four patients with myasthenia gravis were studied, divided into two groups. Group 1 included 13 subjects (eight women and five men aged 23-64) with mild generalised myasthenia gravis, and group 2 was composed of 15 patients (11 women and four men aged 23-69) with moderate generalised myasthenia gravis. A control group comprised 15 healthy persons with a similar age and sex distribution. Spirometric measurements and maximal respiratory pressures were performed under basal conditions in all subjects, and the rate and depth of breathing and the inspiratory occlusion pressure in the mouth in the first 0.1 second $\left(P_{0.1}\right)$ were measured. Results - No difference was detected for parameters of breathing pattern between patients in group 1 and control subjects, although $P_{0.1}$ was higher in those in group 1. Subjects in group 2 had a lower tidal ventilation, shorter inspiratory time, and a higher frequency with a higher $P_{0.1}$ than control subjects.

Conclusions - Mild myasthenia gravis causes increased neuromuscular drive with a normal breathing pattern. Moderate myasthenia gravis is characterised by a more rapid shallow breathing pattern.

(Thorax 1994;49:703-706)

Neuromuscular diseases may result in respiratory failure ${ }^{1}$ and, in some cases, is the first symptom. ${ }^{12}$ For a long time alveolar hypoventilation originating from the progressive fatigue of the respiratory muscle was considered to be the cause of this failure. ${ }^{3}$ Nevertheless, the presence of microatelectasis or pneumonia, and an increase in lung elastance or respiratory work, may contribute to the deterioration of breathing. ${ }^{4}$ Alteration of the ventilatory response to hypercapnia has also been suggested, 5 although the results of a number of studies have been contradictory. ${ }^{6-8}$

Myasthenia gravis is a specific autoimmune disease provoked by the existence of antiacetylcholine receptor antibodies and characterised by skeletal muscle weakness and fatigue. ${ }^{9}$ Respiratory muscle weakness has been studied using maximal inspiratory and expiratory respiratory pressures. ${ }^{1011}$ Few studies have evaluated the effect of stable generalised myasthenia gravis on breathing pattern, and most have been performed in a small number of patients.

This study was undertaken to determine the breathing pattern and the central ventilatory drive in patients with mild and moderate generalised myasthenia gravis, and to evaluate the correlation between these parameters of ventilatory control and the strength of the respiratory muscles.

\section{Methods}

PATIENTS

Twenty four patients with myasthenia gravis (15 women and nine men of mean (SD) age 44 (16) years) were included. The diagnosis was established by a decremental response of the amplitude of the motor response to repetitive nerve stimulation and by a positive edrophonium test. ${ }^{9}$ Osserman ${ }^{12}$ classified myasthenia according to its severity (I, ocular myasthenia; IIa, mild generalised myasthenia; IIb, moderate generalised myasthenia; III, acute severe myasthenia; and IV, late severe myasthenia). We selected two groups which included both mildly and moderately affected subjects. Group 1 consisted of 13 patients (eight women, mean (SD) age 48.7 (13.8) years) of Osserman classification IIa. Group 2 comprised 15 patients ( 11 women, mean (SD) age 40.2 (17.3) years) of Osserman classification IIb (moderate generalised myasthenia). Both groups were compared with 15 healthy subjects of similar sex and age (10 women and five men, mean (SD) age $46.2(10.3)$ years). The patients in group 1 were treated by thymectomy (eight cases), steroids (seven cases), and anticholinesterase (13 cases). Thymectomy was performed in all subjects in group 2, but they also received steroids (eight cases) and anticholinesterase (15 cases). In both groups steroid dosages were $20-40 \mathrm{mg}$ prednisone on alternate days. Two patients in group 1 and five in group 2 complained of breathlessness. Informed consent was obtained from all subjects. The physical characteristics and respiratory function of the three groups are shown in table 1 . 
Table 1 Physical characteristics and respiratory function in patients with myasthenia gravis and control subjects

\begin{tabular}{|c|c|c|c|c|c|c|c|c|c|c|}
\hline & $\begin{array}{l}\text { Age } \\
(y)\end{array}$ & $\begin{array}{l}\text { Men } \\
(\%)\end{array}$ & $\begin{array}{l}\text { Smoker } \\
(\%)\end{array}$ & $\begin{array}{l}\text { Height } \\
(\mathrm{cm})\end{array}$ & $\begin{array}{l}\text { Weight } \\
\text { (kg) }\end{array}$ & $\begin{array}{l}F E V, \\
(\%)\end{array}$ & $\begin{array}{l}F V C \\
(\%)\end{array}$ & $\begin{array}{l}F E V_{l} / F V C \\
(\%)\end{array}$ & $\begin{array}{l}\text { MIP } \\
\left(\mathrm{cm} \mathrm{H}_{2} \mathrm{O}\right)\end{array}$ & $\begin{array}{l}\mathrm{MEP} \\
\left(\mathrm{Cm} \mathrm{H}_{2} \mathrm{O}\right)\end{array}$ \\
\hline Group 1 & $\begin{array}{c}48.7 \\
(13.8)\end{array}$ & 38.4 & 25.0 & $\begin{array}{l}161 \cdot 6 \\
(13 \cdot 8)\end{array}$ & $\begin{array}{c}64 \cdot 3 \\
(11 \cdot 4)\end{array}$ & $\begin{array}{l}91 \cdot 4 \\
(18 \cdot 1)\end{array}$ & $\begin{array}{c}95 \cdot 3 \\
(13 \cdot 3)\end{array}$ & $\begin{array}{c}79 \cdot 6 \\
(6.8)\end{array}$ & $\begin{array}{c}61 \cdot 7 \\
(25 \cdot 6)\end{array}$ & $\begin{array}{c}99.8 \\
(50.9)\end{array}$ \\
\hline Group 2 & $\begin{array}{c}40 \cdot 2 \\
(17 \cdot 3)\end{array}$ & $26 \cdot 6$ & 35.7 & $\begin{array}{c}(15.8) \\
(7.3)\end{array}$ & $\begin{array}{c}63.8 \\
(11.9)\end{array}$ & $\begin{array}{l}90.1 \\
(15.2)\end{array}$ & $\begin{array}{l}92.4 \\
(12.2)\end{array}$ & $\begin{array}{l}81.0 \\
(5.4)\end{array}$ & $\begin{array}{r}49 \cdot 2 \\
(20.7)\end{array}$ & $\begin{array}{c}62 \cdot 8 \\
(18.8)\end{array}$ \\
\hline Controls & $\begin{array}{l}46 \cdot 2 \\
(10 \cdot 3)\end{array}$ & $33 \cdot 3$ & $33 \cdot 3$ & $\begin{array}{l}168.7 \\
(12.3)\end{array}$ & $\begin{array}{c}67 \cdot 2 \\
(9 \cdot 7)\end{array}$ & $\begin{array}{l}101 \\
(15 \cdot 0)\end{array}$ & $\begin{array}{l}103 \cdot 2 \\
(10 \cdot 8)\end{array}$ & $\begin{array}{l}84.5 \\
(6 \cdot 0)\end{array}$ & $\begin{array}{l}91 \cdot 0 \\
(21 \cdot 0)\end{array}$ & $\begin{array}{l}118 \cdot 2 \\
(24 \cdot 6)\end{array}$ \\
\hline \multirow{2}{*}{$\begin{array}{l}\text { Group 1 } \\
v \text { control } \\
\text { Group 2 } \\
v \text { control }\end{array}$} & NS & NS & NS & NS & NS & NS & NS & NS & $<0.05$ & NS \\
\hline & NS & NS & NS & NS & NS & NS & NS & NS & $<0.05$ & $<0.05$ \\
\hline
\end{tabular}

$\mathrm{FEV}_{1}=$ forced expiratory volume in one second $\mathrm{FVC}=$ forced vital capacity; $\mathrm{MIP}=$ maximal inspiratory pressure; $\mathrm{MEP}=$ maximal expiratory pressure.

Values are percentages of patients or mean (SD).

\section{STUDY DESIGN}

Investigations were started at the same time in the morning under basal conditions for all patients. Spirometric values were obtained with the subjects seated. The normal values for lung volumes were those proposed by the European Community for Coal and Steel. ${ }^{13}$

Maximal static inspiratory (MIP) and expiratory (MEP) pressures were measured with a differential pressure transducer (M-163; Sibelmed). When comfortably seated and wearing a noseclip, patients performed maximal respiratory efforts either at residual volume or at total lung capacity against an obstructed mouthpiece with a small leak (internal diameter $0.7 \mathrm{~mm}$ ) to minimise oral pressure artifacts. The manoeuvres were repeated until three measurements sustained for at least three seconds with less than $5 \%$ variability were recorded. The highest value obtained was used for analysis. The reference values for MIP and MEP were those of Wilson et al. ${ }^{14}$

Ventilatory pattern was evaluated while breathing room air, measuring tidal volume (VT), inspiratory time ( $\mathrm{TI}$ ), and total time of the respiratory cycle (Ттот). Subjects, wearing a noseclip, breathed through a mouthpiece while seated in a chair with foot and arm supports. Flow was measured with a pneumotachograph (Jaeger Series 264). Volume was measured by integration of flow signal. Expiratory time (TE), mean inspiratory flow (VT/TI), duty cycle (TI/Tтот), respiratory frequency ( $f=60 /$ Tтот), and instantaneous ventilation $\left(V_{I}=V_{T} \times f\right)$ were calculated. Measurements were performed after a 20 minute period of rest. Values from 10 cycles were averaged for analysis of the results. ${ }^{15}$
Mouth occlusion pressure $0 \cdot 1$ seconds after the beginning of inspiration $\left(P_{0.1}\right)$ was measured by the method of Whitelaw. ${ }^{16}$ Mouth pressure was recorded with a differential pressure transducer (Model DWD, Jaeger). At about 15 second intervals the inspiratory line was occluded without the subject's knowledge for less than 0.5 seconds by means of a pneumatic inflatable balloon (Series 9300; Hans-Rudolph, Kansas City, Missouri, USA) and the mean of at least five measurements was determined. Effective respiratory impedance was calculated by dividing $P_{0.1}$ by VT/TI. The values for dead space and circuit resistance were $70 \mathrm{ml}$ and $0.036 \mathrm{~cm} \mathrm{H}_{2} \mathrm{O} / 1 / \mathrm{s}$.

The results were expressed as mean (SD). Statistical analysis was performed with BMDP Statistical Software (Release 7, 1993). Statistical comparison of the three groups was treated with analysis of variance coupled with pairwise mean comparisons using the Dunnet $t$ test. The association of the parameters of breathing pattern with spirometric data and maximal respiratory pressures was tested using Spearman's correlation, with $\mathrm{p}<0.05$ being considered significant. ${ }^{17}$

\section{Results}

The physical characteristics and respiratory function tests of the three groups are shown in table 1. No significant differences were found in age, sex, smoking habit, weight, height, FEV $_{1}$ (\% predicted), FVC (\% predicted), and $\mathrm{FEV}_{1} / \mathrm{FVC}$ between the control group and patients in groups 1 and 2. Compared with the control group MIP was significantly lower in groups $1(\mathrm{p}<0.05)$ and $2(\mathrm{p}<0.05)$, but MEP was only lower in group $2(p<0.05)$.

Table 2 Mean (SD) breathing pattern and $P_{0.1}$ in the patients with myasthenia gravis and control subjects

\begin{tabular}{|c|c|c|c|c|c|c|c|c|c|c|}
\hline & $\begin{array}{l}V T \\
(l)\end{array}$ & $\begin{array}{l}T_{I} \\
(s)\end{array}$ & $\begin{array}{l}\text { Tтот } \\
(s)\end{array}$ & $f_{\left(s^{-1}\right)}$ & $\begin{array}{l}T E \\
(s)\end{array}$ & $\begin{array}{l}V I \\
(l / \min )\end{array}$ & $\begin{array}{l}V T / T_{I} \\
(l / s)\end{array}$ & TI/TTOT & $\begin{array}{l}P_{0.1} \\
\left(\mathrm{~cm} \mathrm{H} \mathrm{H}_{2} \mathrm{O}\right)\end{array}$ & $\begin{array}{l}P_{0.1} / V T / T_{I} \\
\left(\mathrm{~cm} \mathrm{H}_{2} \mathrm{O} / \mathrm{l} / \mathrm{s}\right)\end{array}$ \\
\hline $\begin{array}{l}\text { Group } 1 \\
\text { Group } 2 \\
\text { Controls }\end{array}$ & $\begin{array}{c}0.5 \\
(0.1) \\
0.4 \\
(0.0) \\
0.5 \\
(0.1)\end{array}$ & $\begin{array}{c}1.4 \\
(0.3) \\
1.1 \\
(0.2) \\
1.7 \\
(0.4)\end{array}$ & $\begin{array}{c}3.4 \\
(0.6) \\
2 \cdot 7 \\
(0.4) \\
3 \cdot 6 \\
(0.8)\end{array}$ & $\begin{array}{c}18 \cdot 2 \\
(3 \cdot 6) \\
23 \cdot 0 \\
(3 \cdot 5) \\
17 \cdot 0 \\
(3 \cdot 2)\end{array}$ & $\begin{array}{c}2.0 \\
(0.5) \\
1.6 \\
(0.4) \\
1.9 \\
(0.4)\end{array}$ & $\begin{array}{c}9 \cdot 3 \\
(1 \cdot 2) \\
9 \cdot 2 \\
(1.9) \\
9 \cdot 5 \\
(2 \cdot 3)\end{array}$ & $\begin{array}{c}0.4 \\
(0 \cdot 1) \\
0.4 \\
(0.1) \\
0 \cdot 3 \\
(0 \cdot 1)\end{array}$ & $\begin{array}{c}0.4 \\
(0.1) \\
0.4 \\
(0.1) \\
0.5 \\
(0.0)\end{array}$ & $\begin{array}{c}2 \cdot 4 \\
(0 \cdot 7) \\
2 \cdot 2 \\
(0 \cdot 7) \\
1 \cdot 5 \\
(0 \cdot 2)\end{array}$ & $\begin{array}{c}6.8 \\
(2.3) \\
6.6 \\
(1.2) \\
4.9 \\
(1 \cdot 1)\end{array}$ \\
\hline $\begin{array}{l}\text { Group } 1 \\
v \text { control } \\
\text { Group } 2 \\
v \text { control }\end{array}$ & $\begin{array}{l}\text { NS } \\
<0.01\end{array}$ & $\begin{array}{l}\text { NS } \\
<0.01\end{array}$ & $\begin{array}{l}\text { NS } \\
<0.05\end{array}$ & $\begin{array}{l}\text { NS } \\
<0.01\end{array}$ & NS & NS & NS & NS & $\begin{array}{l}<0.05 \\
<0.05\end{array}$ & $\begin{array}{l}<0.05 \\
<0.05\end{array}$ \\
\hline
\end{tabular}

$\mathrm{VT}=$ tidal volume; $\mathrm{TI}_{\mathrm{I}}=$ inspiratory time; $\mathrm{TTOT}=$ total time of respiratory cycle; $\mathrm{f}=$ respiratory frequency; $\mathrm{TE}=$ expiratory time; $V_{I}=$ instantaneous ventilation; $\mathrm{VT} / \mathrm{TI}=$ mean inspiratory flow; $\mathrm{TI} / \mathrm{T}$ TOT $=$ duty cycle; $\mathrm{P}_{0.1}=$ mouth occlusion pressure $0 \cdot 1$ seconds after beginning of inspiration; $\mathrm{P}_{0.1} / \mathrm{VT} / \mathrm{TI}_{\mathrm{I}}=$ respiratory impedance. 
The mean characteristics of the breathing pattern and $P_{0.1}$ in the patients and control group are shown in table 2 . No difference was detected for parameters of breathing pattern between patients in group 1 and control subjects. $P_{0.1}$ and $P_{0.1} / V T / T_{I}$ were significantly greater in the patients in group $1(\mathrm{p}<0.05)$.

Compared with the control group, patients in group 2 had significantly lower mean values of VT $(p<0.01)$, TI $(p<0.01)$, and higher $f$ $(p<0.01)$. However, their mean VI did not differ from the control group. Mean inspiratory flow was similar in the control patients and those in group 2, whereas the $P_{0.1}$ was greater in patients in group $2(p<0.05)$. Both findings give rise to a greater effective inspiratory impedance $(p<0.05)$.

Finally, considering all the patients with myasthenia gravis, no significant correlation was found between MIP and MEP and $P_{0.1}$, although a statistically significant correlation was present $(p<0.05)$ between MIP and $P_{0.1}$ in the patients in group $1(r=0.68)$.

\section{Discussion}

These findings confirm that the maximal respiratory pressures deteriorate as myasthenia gravis advances without any concomitant fall in FVC, and are in agreement with those of others. ${ }^{311819}$ The weakness of the respiratory muscles may be caused by several factors: defects in neuromuscular transmission, steroid myopathy or necrosis, atrophy, and accumulation of lymphocytes in muscles of patients with myasthenia gravis. ${ }^{20}$ In addition it has been shown that in the presence of antiactin, antimyosin, and antisarcoplasmic reticulum antibodies there is a decrease of calcium uptake by the sarcoplasmic reticulum and, therefore, of the tension of the myofibrils. ${ }^{21}$ In patients with mild generalised myasthenia gravis (IIa) MIP was lower than the control group, whereas no significant reduction in MEP was found. MIP could therefore be considered as an earlier parameter of muscular deterioration in these patients. It is also known that MIP is a good measure of muscle force in other neuromuscular diseases such as Duchenne's disease, deteriorating before other measurements of lung function. ${ }^{1014}$ Nevertheless, other authors ${ }^{22} 23$ have found a greater deterioration of MEP in patients with myasthenia gravis and in volunteers receiving curare.

The breathing pattern in moderate generalised myasthenia gravis showed a lower VT and $T I$, and a greater $f$, as in previous studies. ${ }^{19}$ This kind of breathing - more shallow and rapid - is not exclusive to myasthenia gravis and has been observed in other neuromuscular diseases. ${ }^{1624}$. Afferent nerves from respiratory muscle, rib cage, and lungs could act centrally to arrest inspiration and, as a result, shorten Tr. ${ }^{725}$ The higher frequency resulting from shortened inspiratory time might lead initially to a reduction in $\mathrm{PaCO}_{2}$. Nevertheless, the lower VT gives rise to an increase in the $\mathrm{VD} / \mathrm{VT}$ ratio which reduces effective ventilation. In the long term these events could cause an increase in $\mathrm{PaCO}_{2} \cdot{ }^{19}$
The main inconvenience found when the mean inspiratory flow is used to evaluate the central ventilatory drive in patients with muscle fatigue is that this parameter may be underestimated..$^{46}$ Even though some authors ${ }^{27}$ have'suggested, that $P_{0.1}$ can also be underestimated, others ${ }^{25}$ have found no evidence for this. These results could explain the higher $P_{0.1}$ and similar VT/TI in the patients with myasthenia gravis compared with the control group.

In our patients the central ventilatory drive measured by $P_{0.1}$ was increased as in myotonic dystrophy, ${ }^{6}$ Friedreich's ataxia, ${ }^{28}$ or after curare. ${ }^{26}$ Nevertheless, the elevation of $P_{0.1}$ does not increase ventilation because the effective impedance is also increased. The increase of the effective respiratory impedance found in patients with myotonic dystrophy is not due to the increase of the effective lung impedance. ${ }^{6}$ The obstruction of breathing during inspiration may therefore be only attributed to raised extrapulmonary resistance.

How the respiratory system detects muscle weakness and increases the nervous drive is not known. Two mechanisms - spinal and supraspinal - have been proposed. The first may be due to the excitation provoked by the muscle spindles or Golgi tendon organ to the respiratory motor neurones when muscles fail to generate tension. ${ }^{7}$ The latter comprises stimulation of the respiratory centres from vagal reflexes which depends on $V T .{ }^{29}$

Our most important finding is the description of changes between mild and moderate grades of myasthenia gravis. We have shown that the central ventilatory drive is increased in the mild grade of the disease (IIa), with tidal volume remaining normal. The increase in $\mathbf{P}_{0.1}$ is inversely related to the deterioration of muscle strength as measured by MIP. Nevertheless, when the disease progresses to grade IIb the central ventilatory drive fails to increase and tidal volume falls. The reduction in muscle strength causes the changes in the breathing patterns and the central ventilatory drive.

In conclusion, changes of ventilatory control in patients with myasthenia gravis are a response to muscle weakness; thus tidal volume falls when the muscles become too weak to respond to an increase in central drive.

1 Serisier DE, Mastaglia FL, Gibson GJ. Respiratory muscle function and ventilatory control: I. In patients with moto neurone disease. II. In patients with myotonic dystrophy. $Q \mathcal{F}$ Med 1982;202:205-26.

2 Mier A, Laroche C, Green M. Unsuspected myasthenia gravis presenting as respiratory failure. Thorax 1990;45:422-3.

3 Newsom-Davis J, Loh L. Alveolar hypoventilation and respiratory muscle weakness. Bull Eur Physiopathol Respir 1979;15(Suppl):45-51.

4 Baydur A. Respiratory muscle strength and control of ventilation in patients with neuromuscular disease. Chest 1991;99:330-8.

5 Gilmartin JJ, Cooper BG, Griffiths CJ, Walls TJ, Veale D Stone TN, et al. Breathing during sleep in patients with myotonic dystrophy and non-myotonic respiratory myotonic dystrophy and non-myotonic

6 Begin $R$, Bukn Pan R, Bureau MA, Lupien L, Bernier JP, Lemieux B. Pathogenesis of respiratory insufficiency in myotonic dys-

7 Grinman S, Whitelaw WA. Pattern of breathing in a case of generalized respiratory muscle function weakness. Chest 983;84:770-2. 
8 Begin R, Bureau A, Lupien L, Lemieux B. Control and modulation of respiration in Steinert's myotonic dystrophy. Am Rev Respir Dis 1990;121:281-9.

9 Kelly BJ, Luce JM. The diagnosis and management of neuromuscular diseases causing respiratory failure. Chest 1971;99:1485-94.

10 Smith PEM, Calverley PMA, Edwards RHT, Evans GA, Campbell EJM. Practical problems in the respiratory care of patients with m

11 Mier-Jedrzejowicz AK, Brophy C, Green M. Respiratory muscle function in myasthenia gravis. Am Rev Respir Dis muscle function in

12 Osserman KE, Genkis G. Studies in myasthenia gravis: review of a twenty-year experience in over 1200 patients. Mount Sinai f Med 1971;38:497-536.

13 European Community for Coal and Steel. Standardization of the lung function tests. Bull Eur Physiopathol Respir 1983;19(Suppl 5):1-95.

14 Wilson SH, Cooke NT, Edwards RHT, Spiro SG. Predicted normal values for maximum respiratory pressures in caucasian adults and children. Thorax 1984;39:535-8.

15 Contreras G, Gutierrez M, Beroiza R, Fantín A, Oddó $H$, Villarroel L, et al. Ventilatory drive and respiratory muscle function in pregnancy. Am Rev Respir Dis 1991;144:837-41.

16 Whitelaw W, Derenne JPh, Milic-Emili J. Occlusion pressure as a measure of respiratory center output in consure as a measure of respiratory center output in con-
scious man. Respir Physiol 1975;23:181-9.

7 Altman DG, Gore SM, Gardner MJ, Pocock SJ. Statistical guidelines for contributors to medical journals. $B M \mathcal{Y}$ 1983;286:1489-93.

18 Newsom-Davis J, Goldman M, Loh L, Casson M. Diaphragm function and alveolar hypoventilation. $Q$ f $\mathrm{Med}$ 1976;177:87-100.
19 Spinelli A, Marconi G, Gorini M, Pizzi A, Scano G. Control of breathing in patients with myasthenia gravis. Am Rev Respir Dis 1992;145:1359-66.

20 Ellis EF. Steroid myopathy. $\mathcal{f}$ Allergy Clin Immunol 1985;76:431-2.

21 Pagala MKD, Nandakumar NV, Venkatachari SAT, Ravindran K, Namba T, Grob D. Responses of intercostal muscle biopsies from normal subjects and patients with myasthenia gravis. Muscle Nerve 1990;13:1012-22.

22 Braun MTN, Narinder SA, Rochester DF. Respiratory muscle and pulmonary function in polymiositis and other proximal myopathies. Thorax 1983;38:616-23.

$23 \mathrm{Gal}$ TJ, Arora NS. Respiratory mechanics in supine subjects during progressive partial curarisation. $\mathcal{f} A p p l$ iol 1982;52:57-63.

24 Borel CO, Tilford C, Nichols DG, Hanley DF, Traystman RJ. Diaphragmatic performances during recovery from acute ventilatory failure in Guillain-Barré syndrome and myasthenia gravis. Chest 1991;99:444-51.

25 Begin R, Bureau MA, Lupien L, Lemieux B. Control of breathing in Duchenne's muscular dystrophy. $A m \mathcal{F}$ Med 1980;69:227-34.

26 Smith PEM, Calverley PMA, Edwards RHT, Evans GA, Campbell EJM. Practical problems in the respiratory care of patients with muscular dystrophy. $N$ Engl $f \mathrm{Med}$ 1987;316:1197-205.

27 Begin R, Lupien L, Bureau MA, Lemieux B. Regulation of respiration in Friedrich's ataxia. Can $\mathcal{f}$ Neurol Sci respiration in

28 Holle RHO, Scoene RB, Pavlin EJ. Effect of respiratory muscle weakness on $\mathbf{P}_{0.1}$ induced by partial curarization. $\mathcal{f}$ Appl Physiol 1984;57:1150-7.

29 Nochomovitz ML, Goldman M, Mitra J, Cherniack NS Respiratory responses in reversible diaphragm paralysis. f Appl Physiol 1981;51:1150-6. 